\title{
THE ROLE OF EFFECTIVE FACTORS IN UTAUT MODEL ON BEHAVIORAL INTENTION
}

\author{
Richa N. Agarwal \\ Institute of Management Studies, Ghaziabad, India \\ richa.n.agarwal11@gmail.com
}

\begin{abstract}
Digital transactions are growing globally. India has embarked on this journey but still lags behind, in comparison to other countries. The paper attempts to find factors which affect behavioral intention among small merchants for adopting technology. Small merchants in unorganized sector are an important part of Indian business framework. The paper is a deductive research wherein it makes UTAUT model its base and adapts to the Indian context. The paper tests models and hypotheses with the help of Structural Equation Modelling (SEM). Few variables like performance expectancy, effort expectancy and habit were found to have an effect on intention to adopt cashless method; surprisingly factors profound to Indian consumers such as trust, perceived value and social influence were not found to have an effect on behavioral intension. The study is useful for the digital payment service providers, telecom companies, small merchants, Government and society. It also proposes strategic initiatives to boost digital transactions. It is unique as the survey is in the unorganized sector.
\end{abstract}

Keywords: Digital methods, payments, India, cashless economy, digitization

\section{INTRODUCTION}

Digital revolution has become the most significant technology trend globally (Kowalsky, 2015). The difference between the earlier revolution and the digital revolution is that the internet is inherently global, which can be utilized by developed and developing nations equally (Kravchenko et al., 2019). Digitalization continues to expand and impact the economy. Revolution in Information and communication technology is creating new paths for developing economies like India and overcome disabilities which cripple growth. Digitalization contributes to the national economy as it decreases the operational cost and increases efficiency (Mittal and Kumar, 2018; Plumb and Zamfir, 2008). Massive transformation is happening with a new type of business which is called e-business containing esignature, mobile banking, and e-payments, creating efficiency in corporate and individual life (Dirican, 2015; Zamfir, 2013). The growth of the payments component also points to the imperative to develop and continually refresh sound payments strategies in order to remain competitive a market being 
reshaped by technology, new competition, and customer demands (Bansal et al., 2018, Carstea et al., 2017).

The level of cashless transactions is one of the important indicators of the country's economic growth and access to digital payment is of great importance for the entrepreneurs (Jakubowska, 2017). Economic activities need the support of the Payment system, as it fuels business across nations (Subrahmanya \& Puttana, 2018). New avenues are opened for companies. Many e- commerce companies, telecom companies, apps are eyeing to tap the potential of payment markets. It would be quicker to transact both for the customers and employees. These technological changes are not only transforming the business world and civil society, but it will revolutionize the way the government and organization does its business and the way public life is conducted (Popescu et al., 2018).

- $\quad$ Digitalization and transactions - Transactions happening on digital platforms are called digital transactions. The key feature is that transactions occur without the usage of cash. Financial technology companies collaborate with various sectors (Frankenfield, 2018). The instruments for these transactions are debit, credit cards, mobile wallets, mobile apps, net banking, National electronic fund transfer, immediate payment service, and another similar instrument. Over the last decade, the payment industry has recorded a massive growth with new providers, platforms, and tools. It has proliferated in Africa, Asia, and Latin America (Clement, 2019). In the Mckinsey report, it is pointed out that the growing popularity of alternative payment solutions further give thrust to digitalization (Bansal et al., 2018).

- $\quad$ Digital payments in India - To increase digital payment, Indian government has launched many schemes and given approvals to many policies. Seeing the vast future market many fin-tech companies are trying to enter the market, offering various digital payment solutions. The government has already invested huge amount in the Indian digital payments industry with payment gateways and mobile wallets. The recent move of RBI (Reserve Bank of India, 2019), providing license to 11 companies to set up payment banks is a major booster to digital shift in the economy. India as a country poses many challenges as a diverse country. Normally, cash-free businesses are being adopted in financially cohesive countries; wealthy regions where people are tech- savvy, educated, and are trusting for security. Countries that deal with diversity, in terms of age, class, status, incomes are less likely to go cash-free, as doing so would hurt their bottom line (Bushnell, 2019). India has a lower level of increase in consumption by cashless methods compare to other emerging economies like $4.89 \%$ in China, 1.070\% in Russia and1.147\% in Brazil (Mukhopadhyay, 2016). 
- $\quad$ Digital payments and demonetization - The Government of India banned the vast majority of the nation's banknotes in a move referred to as 'demonetization,' with the stated goals of fighting corruption, terrorism, and eventually expanding digital transactions (Pal et al., 2018). Major boost came during demonetization when Indian masses started using digital payments (Mukherjee, 2019). Digital payments have increased manifold after demonetization came into effect in 2016 (Sridhar, 2018). As per data available with the RBI and National Payments Corporation of India (NPCl), the increase in digital payments has been profound between September 2016 and September 2018 (Gopakumar, 2019).There has been an increase in cashless transactions after demonetization (Maji, 2017), but the growth is in small components (Wilson, 2017).

The purpose of the paper is to study, Indian small merchants who deal in unorganized sectors and some of them are illiterate. Moreover, they do not wish to disclose their transactions to save tax. They are rigid in their habits. Research tells us that small businesses are slower to adopt new technology (Bushnell, 2019). Some mindset issues are holding back many from embracing the more modern platforms (Dhanorkar, 2017). Small merchants are not adopting new technology as they do not want to disturb their age-old practice which is working. They say, "They're not adopting any new tech because they don't need anything else" (Bushnell, 2018). The study becomes essential in India 's context. To include unbanked population, India needs to adopt transact digitally. It will bring transparency in the system and it will help the population who do not have access to banks for transactions. It will also widen tax base. The study focuses on small merchants of the unorganized sector, which also has a presence in rural India and, makes an integral part of the Indian business framework. Small merchant's adoption of cashless methods becomes crucial for India's transition from cash to cashless economy. The purpose of the study is to give an insight of small merchants' mindsets.

\section{LITERATURE REVIEW}

Digital technologies are creating opportunities for the creation and development of business (Kravchenko et al., 2019; Porter \& Heppelmann, 2014). Digital devices have opened huge opportunities in the businesses, and these have the potential to revolutionize the way we function (Geisberger et al., 2011; Bauernhansl et al., 2014). Massive transformation in e-business creates efficiency in corporate and individual life (Dirican, 2015). An increase in cashless transactions curbs the shadowy economy (Jamsheer, 2018) stopping fake currency and fraudulent practices, as the transactions are traceable. Secure payment system and shopping in the virtual environment increased internet-based trade practices in the past recent years (Tunay et al., 2015). Globally the primary means of payment are credit cards (Asia and North America) and debit cards (Africa), but digital payment systems especially mobile 
payment systems (e-wallets) are also gaining momentum (Western Europe, China \& India) (Kravchenko et al., 2019). Subrahmanya and Puttana (2018) find that demonetization and subsequent reduction in cash have pushed Indian public to digital platforms and the increased supply of currency notes thereafter has again brought back the cash transaction habit. The impetus for the use of the electronic mediums of transactions further enhanced due to demonetization. Payments company executives estimate that card transactions in towns have doubled in the two years since demonetization. Based on the Reserve Bank of India (RBI) data, we can say that demonetization did have a considerable positive impact on digital payments (Shashidhar, 2018). Utilizing mobile phones to make payments instead of opting for the traditional modes of payment has increased tremendously since demonetization. Schneider $(2011 ; 2013)$ found that there is a negative correlation between cashless transaction methods and shadowy economy. Bolt et al. $(2005,2008)$ found that using cashless payment instruments saved 0.7 billion Euro for Norway ( $0.35 \%$ of GDP) and 2.9 billion Euro for the Netherlands $(0.61 \%$ of GDP). Krueger and Seitz, (2014) suggests that saving increases, if economy graduates to cashless payments. Zandi et al. (2013) found that $983 \$$ were added to their real GDP because of cashless methods.

Bolt et al. (2008) and Hasan et al. (2013) found a positive correlation between cashless methods and the economy. Therefore, promoting e-payment is necessary for the economy (Borcuch, 2011). Madzharova (2014) studied the correlation between revenue and cashless transactions. Most small business owners resist new technology (Bushnell, 2019; Kwatra, 2019). Low usage of technology has been a critical factor for low productivity (Sichel, 1997). In India, the barrier is more psychological and social. The merchants do not want to adopt digital payment as they find it cumbersome and increasing their tax liability (Ligon et al., 2019). For small businesses, the decision on whether to accept card payments is an important one as it can affect everything from the day-to-day running of your business to the profit generated (Moss, 2019). Chattopadhyay et al. (2018) says that the retailers are more habitual of using cash in their transactions and hence find it much easy and spontaneous choice. Corporates want to capture the cashless transactions among small shop- keepers market as they constitute a major share of business in India. But most of them are reluctant to go cashless (Mukherjee, 2019). UTAUT Model (Unified Theory of Acceptance and use of Technology) incorporates both human and social variables (Venkatesh et al., 2003). UTAUT has been accepted as a valid model for testing, especially technology acceptance (Venkatesh et al., 2003). It has evolved from various previous studies, conducted for different technologies being accepted by multiple user segments. UTAUT model has different independent variables such as performance expectancy, effort expectancy, social influence, perceived value, trust, facilitating condition and habit etc. Many studies 
have added or deleted factors as per their studies. In this study researcher has taken few variables after pilot study and have studied its effect with the dependent variable "Behavioral Intension". Those are performance expectancy, effort expectancy, social influence, perceived value, trust, and habit.

"Performance Expectancy" is expectation from the performance of any new system than using the conventional method. The factor is related to usefulness; namely, performance expectancy is many times shown to be the strongest predictor of behavioral intention (Venkatesh, 2003). About how much effort in terms of time and effort is required in performing tasks is "Effort Expectancy "(Venkatesh et al, 2003). It defines the easiness of consumer associates with technology. How much clarity, understandability, flexibility, and ease consumer experiences while using a system creates a perception for the technology (Bandyopadhyay and Fraccastoro, 2007). "Social influence" is when an individual perceives someone, having authority, and behaves accordingly and influences his decision (French \& Raven, 1959; Kelman, 1958;). Deutsch and Gerard (1955) say about social influence, "Influence to accept information from another as evidence about reality." In the present context, if a co-worker suggests that a system might be useful, a person may come to believe that it is valuable, and in turn form an intention to use it (Venkatesh and Davis, 2000). Turel et al. (2007) talk about the multidimensionality of the "Perceived Value" factor and its impact on behavioral intention. They discuss that there is a trade-off of price, social, emotional, and quality for the adoption decision. Chin-Lung (2016) developed a model on perceived value and social influences. (Kim et al., 2013) explain mobile user engagement intention through user's motivations, perceived value, and satisfaction. Pavlou (2003) integrates trust and perceived risk, to study the uncertainty of the e-commerce environment. Kesharwani \& Bisht (2012) reveals that users vary in adopting technology as there is a lack of trust factor. There is a negative relation to adopt and trust factor. Haji (2013) suggests trust is an essential issue in e- commerce. Zhou (2011) opines that Initial trust affects perceived usefulness, and both factors predict the usage intention. "Habit" is an important aspect when an individual leaf or adopt a new technology. Habits are a strong predictor of behavior (Bandyopadhyay and Fraccastoro, 2007). Habit's (Kim and Malhotra, 2005) key feature is that it is automatic (Limayem et al., 2007). Chattopadhyay et al. (2018) imply that even if the retailers do not consider carrying, storing and keeping an account of cash to be the easiest thing, they are more habitual of using cash in their transactions and hence find it much easy and spontaneous. "Behavioural Intention" as a dependent variable and as a predictor of technology acceptance is a critical element (Taylor and Todd, 1995). Many studies have addressed "behavioural Intension" (Burke, 2002). 


\section{RESEARCH METHODOLOGY}

The questionnaire was adapted based on previous literature, discussed above, that focused on technology adoption. The project is based on deductive reasoning, which means, based on theories, the research model is developed. Here Technology acceptance theories are used to generate the research model and hypotheses. The method was a quantitative approach. The main instrument in the questionnaire was on seven -point-Likert scale. The survey was divided into two main divisions, the first, covering the constructs of the adapted model and the second for demographic background. A pilot study was conducted to improve the questions. Only 203 questionnaires were filled correctly out of 230 . Reliability tests are used to check the reliability of the variables. The study was conducted in one of the busiest markets of Delhi, India. The sample consisted of small and very small merchants such as vegetable vendors, pawn shops (betel leaf), cloth shops, and small jewelry shops. It is a part of a sponsored project. A total of 9 locations were surveyed. There were male and female shop keepers. There were Wholesale and retail shops.

\subsection{Research Model and Hypothesis}

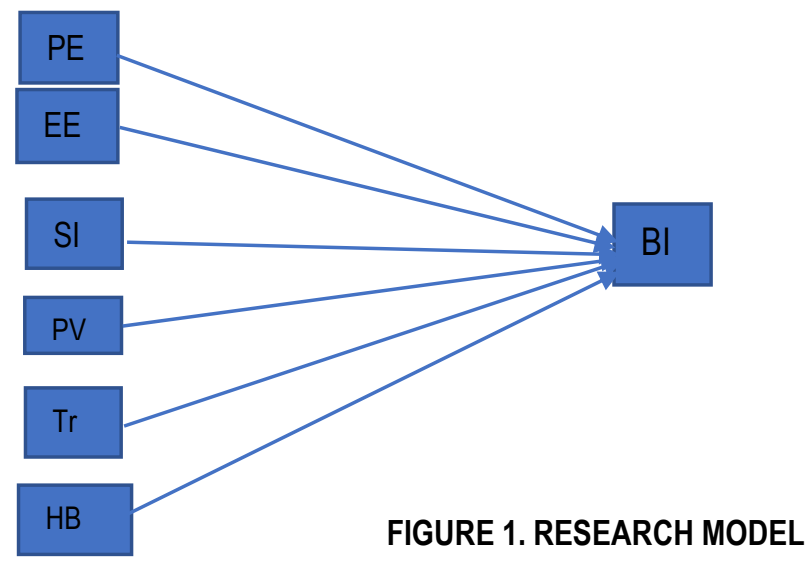

Source: Adapted from The UTAUT model Source: Venkatesh et al. (2003)

Independent variables - PE (Performance Expectancy), EE (Effort Expectancy), SI (Social Influence), PV(Perceived Value), HB (Habit), TR(Trust) having an effect on dependent variable BI (Behavioural Intension) to adopt cashless payments method.

H1. Performance expectation influences the intention of adopting cashless methods among small merchants.

H2. Effort expectation influences the intention of adopting cashless methods among small merchants.

H3. Social influence has an effect on the intention of adopting cashless methods among small merchants. 
H4. Perceived value influences the intention of adopting cashless methods among small merchants.

H5. Trust influences the intention of adopting cashless methods among small merchants.

H6. Habit has an effect on with the intention of adopting cashless methods among small merchants.

Data was not normal however AMOS software was used for the following reasons.

- Hair et al (2006) conclude that PLS is not an appropriate alternative for SEM. SEM works with approximately 150-200 responses to produce findings that will generalize. SEM Does not over inflate factor loadings and is preferred by psychological and social sciences researchers. Whereas PLS needs several hundred responses to produce path results. It Inflates component loadings due to the inclusion of error variance (Rouse and Corbitt, 2008).

- Critical lines of argument within the management and psychology literature assert that there is no reason to use PLS path modelling. Referring to PLS path modeling, Ronkko et al. (2015) assert, "... it is very difficult to justify its use for theory testing over [factor-based] SEM..." Writing in a psychological journal, Ronkko et al. (2015) conclude, "... PLS should not be adopted as a tool for psychological research." Factor-based SEM, it is argued, has a built-in mechanism accounting for measurement error which composite-based PLS path modelling lacks, leaving PLS path models vulnerable to the negative consequences of measurement error in a way that factor-based structural equation models are not (Rigdon, 2016).

- Antonakis et al. (2010) declared, "... there is no use for PLS whatsoever...Dijkstra (2010) deemphasized the "normality" issue in discussions of which software to adopt: in employing either method one is not required to subscribe to normality ; they are "just" different ways of extracting information from second-order moments. If your indicators are categorical and you employ PLS your estimates will be biased (Schuberth et al., 2018). Moreover, if your indicators are continuous and non-normally distributed, it is not an argument to favor PLS (Dijkstra, 2015; Rigdon, 2016).

\section{ANALYSIS}

4.1. STRUCTURAL EQUATION MODELLING - Structural Equation modeling is used (Hair et al., 2005) to analyze the effect between latent variables: performance expectation, effort expectation, social influence, perceived value, trust and habit, and the dependent variable "behavioral intention". The structural equation model is formed by the junction of two models, the measurement and the structural model (Hair et al., 2009). After the analysis of the effect represented in the theoretical model, the proportion of variability (R2) of the dependent construct behavioral intention was evaluated. We followed the two phases. The first, the assessment of the measurement model, verified the reliability of the internal consistency of the constructs through composite reliability which must have values greater than 
0.5. Then to analyze the Convergent Validity the unidimensional of the constructs using average variance extracted (AVE), with a minimum value of 0.5 (Fornell \& Larcker, 1981). Finally, discriminant validity was assessed by the method of crossed load values (Henseler et al., 2009) to verify that the square roots of the AVE's were larger than the correlations between the constructs. The second phase, the assessment of the structural model, started from obtaining the coefficient of determination (R2) between the independent variables and the dependent variable (behavioral intention) to indicate its variability, which is explained by the dependent variables. Its value ranges from 0 to 1 , and the closer to 1 , the greater the proportion explained.

4.2. THEORETICAL MODEL VALIDATION - The path diagram shows the effect of latent variables of the model and behavioral intention. A strong effect of items with their constructs was observed in the complete model estimated by the AMOS software since the loads shown were factorials above 0.5 (Fig 1). CMIN (Chi square value) is 3.29 , which is less than 5 and indicative of model fit. Most of the fit indices meet the requirements for SEM analysis; even though the values for GFI (Goodness of Fit) do not exceed 0.9 (the threshold value), they still met the requirement suggested by (Baumgartner and Homburg,1996) (Homburg and Baumgartner,1995), and (Doll et al., 1994): the value is acceptable if above 0.8. So GFI is .817, which shows the model fit. GFI and AGFI (Adjusted Goodness of Fit) are known to depend on the sample size.

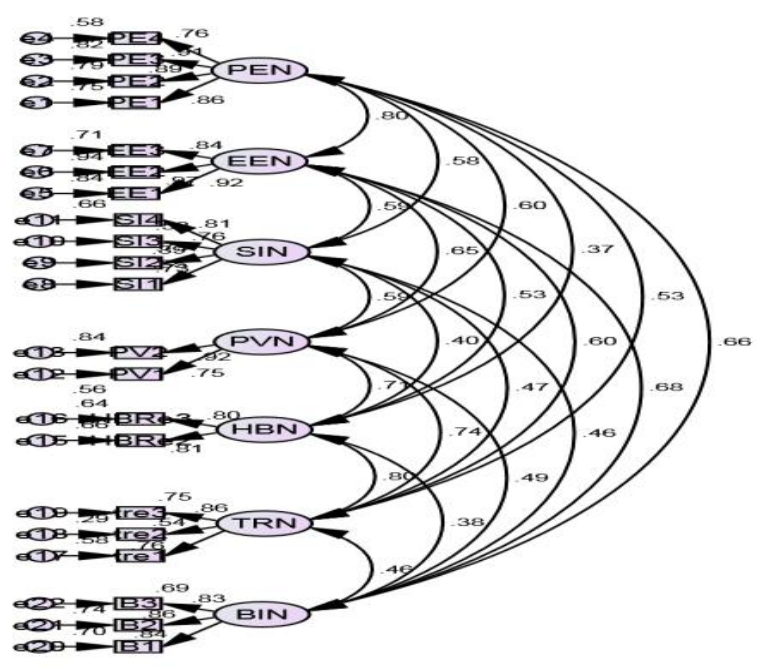

FIGURE - 2 -MEASUREMENT MODEL

Source - (self-compiled by the author)

(Effect of the independent variables - PEN(performance expectancy), EEE(effort expectancy, SIN (Social Influence), PVN( Perceived Value), HBN (Habit), TRN(Trust) on dependent variable BIN (Behavioural Intension)) 
The RMSEA values for the model are .10, which again tells that the model is close to fit. Though it is said normally, that RMSEA should be less than .10, it is also found that in some cases little flexibility should be there, as Chen et al. (2008) found in his study that there is little empirical support for the use of .05 or any other value as universal cut-off values to determine adequate model fit, regardless of whether the point estimate is used alone or jointly with the confidence interval. The authors' analysis of the choice of cut-off values depend on model specifications, degrees of freedom, and sample size. Therefore, as the sample size was small, RMSEA values being close .10 is adequate to be model fit. The result of the test of significance of the theoretical model ( $p$-value) revealed the need to remove the trust construct, since its effect on the variable behavioral intention was not significant ( $p$-value $>0.05$ ). With the removal of this variable, the final model was obtained (Fig. 2). All the constructs presented higher values to the level proposed by Chin (1998) for evaluation of the measurement model, which is 0.7 for composite reliability. Besides, they presented convergent validity, with AVE (average extracted variance) above 0.5 (Fornell and Larcker, 1981) and discriminant validity, with validation through the criterion of cross-loads, where each item showed greater factorial load for the construct to which it belongs. Of the six hypotheses developed for the model proposed, $\mathrm{H} 3, \mathrm{H} 4$ and $\mathrm{H} 5$ were not confirmed. All others, $\mathrm{H} 1, \mathrm{H} 2$, and $\mathrm{H} 6$ were ratified, showing, the three factors' (PE, EE and HB) effect on the intention to adopt a future digital payment service from the perspective of small shop keepers.

FIGURE 3 - STRUCTURAL MODEL

Source- (Self - Compiled by the Author)

New Model exhibiting Effect of performance expectancy (PEN), effort expectancy (EEN) and habit (HBN)on Behavioural Intension 
4.3. DISCRIMINANT VALIDITY - Discriminant validity refers to the extent to which factors are distinct and uncorrelated. The rule is that variables should relate more strongly to their own factor than to another factor. Two primary methods exist for determining discriminant validity during an EFA (Exploratory Factor Analysis). If factors do not demonstrate adequate validity and reliability, after confirmatory factor analysis, moving on to test a causal model will be useless. There are a few measures that are useful for establishing validity and reliability: Composite Reliability (CR), Average Variance Extracted (AVE), Maximum Shared Variance (MSV). The thresholds for these values are as follows: Reliability should be when $C R>0.7$; Convergent Validity should be AVE >0.5; Discriminant Validity MSV < AVE.

After imputing the constructs, it is found that all the factors have more than .7 CR but 'Trust.' MSV is also less .646. All the factors are having CR greater than AVE. All the factors have AVE more than .05. AVE is greater than MSV in all the factors.

If convergent validity issues arise, then it means variables do not correlate well with each other within their parent factor; i.e., the latent factor is not well explained by its observed variables. But here we find that there is convergent validity (table 1). If discriminant validity issues arise, then variables correlate more highly with variables outside their parent factor than with the variables within their parent factor; i.e., the latent factor is better explained by some other variables (from a different factor), than by its own observed variables. Here we find that the model has discriminant validity.

TABLE - 1. CONVERGENT VALIDITY OF THE MODEL

\begin{tabular}{|l|l|l|l|l|l|l|l|l|l|l|l|}
\hline & CR & AVE & MSV & ASV & TRN & PEN & EEN & SIN & PVN & HBN & BIN \\
\hline TRN & 0.772 & 0.539 & 0.646 & 0.378 & 0.734 & & & & & & \\
\hline PEN & 0.917 & 0.735 & 0.643 & 0.364 & 0.531 & 0.857 & & & & & \\
\hline EEN & 0.936 & 0.831 & 0.643 & 0.420 & 0.596 & 0.802 & 0.912 & & & & \\
\hline SIN & 0.897 & 0.687 & 0.354 & 0.273 & 0.471 & 0.578 & 0.592 & 0.829 & & & \\
\hline PVN & 0.821 & 0.699 & 0.551 & 0.405 & 0.742 & 0.598 & 0.653 & 0.595 & 0.836 & & \\
\hline HBN & 0.789 & 0.651 & 0.646 & 0.311 & 0.804 & 0.368 & 0.526 & 0.404 & 0.710 & 0.807 & \\
\hline BIN & 0.881 & 0.711 & 0.466 & 0.284 & 0.463 & 0.657 & 0.683 & 0.462 & 0.488 & 0.377 & 0.843 \\
\hline
\end{tabular}




\section{RESULTS AND DISCUSSION}

Today people are not in the habit of transacting through cashless methods. People from $45+$ lack habit in using technology. Overall, the constructs performance expectation, effort expectation and habit explained .58 (R2) of the variance of intention to adopt digital payment methods. After the elimination of the trust construct of the fitted model, performance expectancy indicated the positive effect on (0.39) behavioral intention to adopt mobile payment method.

The result of effort expectation (EE), also demonstrated its positive effect on the behavioral intention (BI) in the study (.35). The same effect is found in the works of Chong (2015), Barbosa and Zilber, (2013), Oye et al. (2014) and Martins et al.(2014), where it was singled out as one of the most significant determinants of intention to adopt the technology. However, it contrasts Gouveia and Coelho, (2007), who did not show this variable as a relevant factor. The analysis of the social influence factor (IS) also did not prove to be relevant in predicting behavioral intention (BI), though Gouveia and Coelho (2007), Oye et al. (2014) and Martins et al. (2014) proved it relevant. Habit shows a positive effect (.23), and Perceived value showed a negative effect (-17). Habit tops the list as a key barrier to adoption in Indian context (68\%). Schuh and Stavins (2013), Salmony, (2011) find it necessary to build a whole new modern payment system from the ground up and to change the existing consumers' habits. It is difficult to break one's habit, however, once it is broken, only then change will occur.

The cash- less system brings along different banking instruments such as POS (Point of sale) systems used for cashless payments, mobile payments, direct debits, internet banking, electronic fund transfer, etc. Implicitly, companies that relate to the production of these products will benefit. Cashless methods reduce the cost of maintaining cash. In 2009-2010, it was estimated that the cost of printing currency notes was INR 2800 Crores (Das and Agarwal, 2010). Also, India is among the countries with the lowest tax collection. The development of cashless transactions creates the potential to reduce the functioning costs of the payment system and to limit the scale of transactions (Schneider, 2011). Cash transactions lead to shadowy economy. Schneider (2013) has pointed to a negative correlation between the shadow economy and the number of cashless transactions. Cashless initiatives are driven by the necessity to limit the shadow economy, but it can also be met with resistance from the society (Polasik \& Maciejewski, 2009). In the countries that have highly advanced cashless transactions, the scale of the shadow economy is smaller (Jakubowska, 2017). Schneider (2006) estimates the size of India's black money economy between $23 \%$ and $26 \%$ of the GDP. With cashless transactions, it will have higher financial transparency. Singh and Bhattacharya (2015) find a strong causality between high currency notes and corruption. It stops the generation of black money (Fatima and Ahmed, 2019). India presently needs to curb terrorist activities with the currency flow, reduce corruption through transparency 
(Jamsheer, 2018). Cashless methods reduce instances of tax avoidance because transaction trails are left (Fatima and Ahmed, 2019). It also presents a tremendous opportunity for the financial inclusion of $1 / 3 r d$ of the country's population that remains 'unbanked'. Millions of Indians who do not have access to the banking system can be included in organized and transparent transactions. Financial inclusion will pave the way for small and medium enterprises. It also reduces the cost of ATMs. It will pave way for universal availability of banking services to all as no physical infrastructure is needed other than digital (Fatima and Ahmed, 2019).

India's major population using cash, forms potential market segments, for mobile payment. Mobile network operators, financial institutions (banks, card companies, payment processors, governments and technology (hardware and software) and service suppliers - can gain from this new service. Many senior citizens are not mobile but are living alone in metros. Digital payments will help them greatly in health care facilities, shopping, and entertainment, education. More affordable options should be launched by the government for people to buy smartphones for cashless transactions (Fatima and Ahmed, 2019). More public charging points need to be installed as the population of India is big.

The article brings together, in the same model of intention to adopt, some of the most commonly used constructs in recent literature to predict the adoption of digital payments but, what makes this study unique is, that it is in Indian context, among small Indian merchants in the unorganized sector. The article contributes in bringing awareness about the UTAUT model in Indian Context. The study revealed that Indian consumer is not bothered about perceived value and social influence, though these two factors are found critical, in previous studies, for Indian consumers as far as culture goes.

As the payment market is set to bloom, the study will help to tap the vast Indian market. Corporates could formulate strategies of segmentation and communication to enhance their market penetration. The Indian market consists of an organized and unorganized sector. As rural India consists of small and very small merchants the study provides the insight to tap that market.

6.1 RECOMMENDATIONS - The study tells, efforts need to be taken to push towards financial literacy coupled with digital literacy for the broader population. Government needs to bring policies wherein people are forced to transact through cashless methods. Gradually it will increase habit. Merely lowering the fees for using digital methods will not help but increasing demand for digital transactions and incentivizing usage will bring change (Ligon et al., 2019). The government can levy more taxes on heavy cash transactions and can give some bonus points to small merchants in tax rebates. The government should especially run training classes on digital methods in rural areas. Training classes will reduce small merchants' fear and would help in breaking their habits. Research tells us that small businesses are slower to adopt new technology (Bushnell, 2019). What is clear is that users' habits 
related to online transactions and usage needs to undergo a drastic change (Dhanorkar, 2017). The government should improve the infrastructural facility. Internet speed should not hamper transactions. Regulatory laws play an important role here in bringing formalization in the business for bringing trust about payment markets (Moss, 2019).

Corporates 'communication strategies should be such to encourage people to use more digital methods. They should use radio, kiosks, internet, social media, TV commercials, and should devise incentives to inculcate habit (Bunea et al., 2019). Companies need to ensure methods are customer friendly keeping in mind the age and education limitation of small merchants. Language can be vernacular.

With most small businesses viewing cashless acceptance as an unappealing value proposition, due to the processing fees and the digital payment process itself (Moss, 2019), organizations and governments need to bring about a change in the transaction habits of people, with cashback, gift schemes. The author suggests that corporates and government should try to positively reinforce habits among merchants who use sometimes and to inculcate the habit in the first-time user. Subrahmanya and Puttana (2018) say that effective policy shifts can alter consumer preferences. Government and corporates can make advertisements, short movies on explaining the importance of cashless transactions. It can also collaborate with NGOs and schools to create influence.

\section{CONCLUSION}

Cashless payments could open the doorway of financial inclusion (Kunt et al., 2014) for the large sections of poor and backward class people who do not have bank accounts but have mobile phones. Cashless payments will arrest a situation where a lot of cash are outside the formal banking system. Corporate organizations will benefit by way of faster access to capital, reduce revenue leakages and reduce cash handling costs. All the benefits can be combined in the two benefits which are particularly important in the Indian context. The first one is promoting financial inclusion and the second is a better usage of money for public benefits. The paper showed the factors impacting the adoption of cashless methods among small merchants. The study had time and money limitations. There is scope for future studies.

\section{REFERENCES}

Antonakis, J., Bendahan, S., Jacquart, P., \& Lalive, R. (2010). On making causal claims: A review and recommendations. The leadership quarterly, 21(6), 1086-1120.

Bandyopadhyay, K., \& Fraccastoro, K. A. (2007). The effect of culture on user acceptance of information technology. Communications of the Association for Information Systems, 19(1), 23. 
Bansal, S., Bruno, P., Denecker, O., Goparaju, M. and Niederkorn, M. (2018). Global payments 2018: A dynamic industry continues to break new ground. Retrieved from: Mckinsey.com:https://www.mckinsey.com/ /media/McKinsey/Industries/Financial\%20Services/Our $\%$ (accessed on 10 October 2019).

Barbosa, R. C. O. and Zilber, M. A. (2013). As caracteristicas competitivas que impactam a adoc ão de inovac ão: um estudo sobre sistemas de pagamentos móveis. Revista de Administra ,cão e Inova ção, 10, 3, 89-114.

Bauernhansl, T., Hompel, T.H. and Birgit,V.H. (2014). Industrie 4.0 in Produktion, Automatisierung und Logistik. Wiesbaden: Springer Vieweg

Baumgartner, H. and Homburg, C. (1996). Applications of Structural Equation Modelling in Marketing and Consumer Research: a review. International Journal of Research in Marketing, 13(2),139-161.

Bolt, W, Humphrey ,D.\& Uittenbogaard,R.( 2008).Transaction Pricing and the Adoption of Electronic Payments: A Cross-Country Comparison. International Journal of Central Banking, vol. 4(1), pages 89-123, March.

Bolt,W.,Humphrey, D. \& Uittenbogaard, R. (2005). The Effect of Transaction Pricing on the Adoption of Electronic Payments: A Cross-Country Comparison. SSRN Electronic Journal. 10.2139/ssrn.871102.

Borcuch, A. (2011). Bankowošć elektroniczna w Polsce (Electronic Banking in Poland). CeDeWu, Warszawa.

Bunea, O. I., Popescu, R. I., \& Zamfir, A. I. (2019). Social Media As A Component Of The Value Chain To Gain Competitive Advantage In Sales. In Proceedings of the INTERNATIONAL MANAGEMENT CONFERENCE (Vol. 13, No. 1, pp. 702-710). Faculty of Management, Academy of Economic Studies, Bucharest, Romania.

Burke, R. R. (2002.). Technology and the customer interface: what consumers want in the physical and virtual store. Journal of the Academy of Marketing Science, vol. 30, no. 4, 411- 432.

Bushnell, M. (2018). The Tech Gap: How Real Small Businesses Adopt Technology. Business. Retrieved from: https://www.business.com/articles/business-community-tech-adoption-survey [Accessed September 2019].

Carstea, G., Corbos, R. A., Popescu, R. I., \& Bunea, O. I. (2017). Analysis of the influence of some indicators on the profitability of the FMCG retail market in Romania. In Proceedings of the 11th International Management Conference "The Role of Management in the Economic Paradigm of the XXI Century ", November 2nd-4th, Bucharest, Romania (pp. 481-492).

Chattopadhyay, S., Gulati, P. and Bose, I. (2018). Awareness and Participation of Small Retail Businesses in Cashless Transactions: An Empirical Study. Management Dynamics in the Knowledge Economy, Vol.6 (2), 209-225.

Chen, F., Curran, P. J., Bollen, K. A., Kirby, J. and Paxton, P. (2008). An Empirical Evaluation of the Use of Fixed Cutoff Points in RMSEA Test Statistic in Structural Equation Models. Sociological methods \& research, 36(4), 462-494.

Chin, W. W. (1998). The partial least squares approach to structural equation modelling. In G. A. Marcoulides (Ed.), Modern methods for business research. USA: Lawrence Erlbaum Associates Inc.

Chong, A. Y. L. (2015). Understanding mobile commerce continuance intentions: An empirical analysis of Chinese consumers. Journal of Computer Information Systems, Vol. 15, 4, 22-30. 
Clement, J. (2019). Challenges of mobile commerce according to merchants worldwide as of March 2018. Retrieved from statista.com: https://www.statista.com/statistics/814241/m-commercechallenges-worldwide (accessed on 17 September 2019).

Das, A. and Agarwal, R. (2010). Cashless Payment System in India- A Roadmap. Retrieved from dspace library: http://dspace.library.iitb.ac.in/jspui/handle/10054/1732.

Deutsch, M., \& Gerard, H. B. (1955). A study of normative and informational social influences upon individual judgment. The Journal of Abnormal and Social Psychology, 51(3), 629-636.

Dhanorkar, S. (2017). What are people's concerns and preferences in cashless payments? Find out. The Economic Times. Retrieved from: economictimes.indiatimes.com/articleshow/56269830.cms?from=mdr\&utm_source [Accessed 2019].

Dijkstra, T. K. (2010). Latent variables and indices: Herman wold's basic design and partial least squares. In V. Esposito Vinzi, W. W. Chin, J. Henseler, \& H. Wang (Eds.), Handbook of partial least squares: Concepts, methods and applications (pp. 23e46). Berlin: Springer-Verlag.

Dijkstra, T. K. and Henseler, J. (2015). Consistent Partial Least Squares Path Modeling. MIS Quarterly, (39: 2) pp.297-316.

Dirican, C. (2015). The Impacts of Robotics, Artificial Intelligence on Business and Economics. Procedia- Social and Behavioral Sciences, Volume 195, $564-573$.

Doll, W. J., Xia, W. and Torkzadeh, G. (1994). A confirmatory factor analysis of the end-user computing satisfaction instrument. MIS Quarterly, 18(4), 357-369.

Fatima, S., Ahmed, S. (2019). Cash to Cashless Economy: Challenges and Opportunities. Sumedha Journal of Management, 8(2), 170-178.

Fornell, C. and Larcker, D. F. (1981). Evaluating structural equation models with unobservable variables and measurement error. Journal of Marketing Research, Vol 18,1,39- 50.

Frankenfield, J. (2018). Financial Technology \& Automated Investing. Retrieved from investopedia: https://www.investopedia.com/terms/d/digital-transaction.asp (accessed on 17 September 2019).

French, J. R. P and Raven, H.B. (1959). The bases of social power. In D, Cartwright(ed.). Studies in Social Power,150-67. University of Michigan. Institute for Social Research.

Geisberger, E., Victoria, M., Keil, P., Niehaus, J., Thiel, C., Fries, H.J.T. (2011). Cyber- physical systems, driving force for innovation in mobility, health, energy and production. Acatech position paper,1-48.

Gopakumar, G. (2019). Digital payments to more than double to $\$ 135.2$ by 2023. Livemint, Policy. Retrieved from: https://www.livemint.com/politics/policy (accessed on 15 September 2019).

Gouveia, J.M., Coelho, A.F.M. (2007). Determinantes da adopção de novas tecnologias de informação e comunicação - o caso da internet móvel em Portugal. Retrieved from dialnet: https://dialnet.unirioja.es/servlet/articulo;jsessionid=A9A1129DD7482669BAE5B1F9E32E0 077. dialnet01?codigo $=2233156$

Hair, J. F, Babin, B., Money, A. H. \&. Samuel, P. (2005). Fundamentos de Métodos de Pesquisa em Administracao. ão. Porto Alegre: Bookman.

Hair, J. F, Black, W. C., Babin, B. J., Anderson, R. E. \&. Tatham, R. L. (2009). Análise Multivariada de Dados. Porto Alegre: Bookman.

Hajli, M. (2013). A research framework for social commerce adoption. Information Management \& Computer Security,21(3), 144-154. 
Hasan, I., De, Renzis, T. and Schmiedel, H. (2013). Retail Payments and the Real Economy ECB Working Paper Series (1572), European Central Bank.

Henseler, J., Ringle, C. and Sinkovics, R. (2009). The use of partial least squares path modelling in international marketing. In Sinkovics, R. and Ghauri, P. (Ed.). New Challenges to International Marketing (Advances in International Marketing, Vol. 20, 277-319). Bingley: Emerald Group Publishing Limited.

Homburg, C. and Baumgartner, H. (1995). Beurteilung von Kausalmodellen. Bestandsaufnahme und Anwendungsempfehlungen. Marketing ZFP, 162 - 176.

Ion, P., \& Andreea, Z. (2008). Use of ICT in SMEs management within the sector of services. Annals of the University of Oradea, Economic Science Series, 17(4), 481-487.

Jakubowska, M. (2017). The role of cashless transactions in the process of limiting the scale of the shadow economy. Copernican Journal of Finance \& Accounting, 6(4), 23-37.

Jamsheer, M. (2018). Demonetized Monetary System and Digital Economy: An Analysis with Reference to the Indian Economy. International Journal on Global Business Management \& Research, 7(1), 15-22.

Kelman, H. C. (1958). Compliance, identification, and internalization: Three processes of attitude change. Journal of Conflict Resolution, Volume 2, 51-60.

Kesharwani, A. \& Bisht, S. (2012). The impact of trust and perceived risk on Internet banking adoption in India. International Journal of Bank Marketing. 30. 303-322. 10.1108/02652321211236923.

Kim, S. S. and Malhotra N. K. (2005). A Longitudinal Model of Continued IS Use: An Integrative View of Four Mechanisms Underlying Post-Adoption Phenomena. Management Science, 51(5), 741-755.

Kim, Y. H., Kim, D. \& Wachter, K. (2013). A study of mobile user engagement (MoEN): Engagement motivations, perceived value, satisfaction, and continued engagement intention. Decision Support Systems. 56. 361-370.

Kowalsky, W(nd.). The European Digital Agenda: Unambitious and Too Narrow. Retrieved from: https://www.socialeurope.eu/european-digital-agenda-unambitious-narrow.

Kowalsky, W.(2015). The European Digital Agenda: Unambitious and Too Narrow. Retrieved from: https://www.socialeurope.eu/european-digital-agenda-unambitious- narrow(accessed 15 September 2019).

Kravchenko O., Leshchenko, M., Marushchak, D., Vdovychenko, Y., and Boguslavska, S.( 2019). The digitalization as a global trend and growth factor of the modern economy. In Monitoring, Modelling \& Management of Emergent Economy. Proceedings of the international conference, SHS Web of Conferences Volume 65, 435-443. Ukraine.

Krueger, M., Seitz, F.(2014). Costs and Benefits of Cash and Cashless Instruments (Deutsche Bundesbank Report).Germany.

Kunt, D.A., Klapper, L.,Singer,D. and Oudheusden , V. P.(2014). The Global Findex Database 2014 Measuring Financial Inclusion around the World (working paper, World Bank Policy Research, 7255, 2014): World Bank.

Kwatra, N. (2019). Indian merchants do not want to go digital. Livemint, Banking . Retrieved from: https://www.livemint.com/industry/banking/indian-merchants-do-not-want-to-go-digital1556187518672.html 
Ligon, E., Malick, B., Sheth , K. and Trachtman, C.(2019). What explains low adoption of digital payment technologies? Evidence from small-scale merchants in Jaipur, India. Journal. Pone 14(7). Retrieved from: https://doi.org/10.1371/journal.pone.0219450.

Limayem, M., Hirt, S., \& Cheung, C. (2007). How Habit Limits the Predictive Power of Intention: The Case of Information Systems Continuance. MIS Quarterly, 31(4), 705-737. doi:10.2307/25148817

Madzharova, B. (2014). The impact of cash and card transactions on VAT collection efficiency. Retrieved from:

https://www.bundesbank.de/Redaktion/EN/Downloads/Tasks/Cash_management/Conference s/2014_09_16_the_impact_of_cash_and_card_transactions_on_vat_collection_efficienc [Accessed on 16 September 2019].

Maji, P. (2017). Demonetisation keeps digital payments up; cashless transactions grow $13.5 \%$ in September. Business Today. Retrieved from: http://www. businesstoday.in/money/banking/ demonetisation-digital-payments cashless-transactions-e- wallets [Accessed 8 February 2018].

Martins, C., Olivera, T. and Popovic, A. (2014). Understanding the Internet banking adoption: A unified theory of acceptance and use of technology and perceived risk application. International Journal of Information Management, 34,1, 1-13.

Mittal, S., Kumar, V. (2018). Adoption of Mobile Wallets in India: An Analysis. IUP Journal of Information Technology, 14(1), 42-57.

Moss, R. (2019). The Benefits of Cashless Transactions for Small Businesses. Retrieved from https://www.totalprocessing.com/blog/the-benefits-of-cashless-transactions,(Accessed September 2019).

Mukherjee, A. (2019). View: Cashless India could be a model for the world. The Economic Times,Banking and Finance. Retrieved from: https://economictimes.indiatimes.com (accessed on 10 October 2019).

Mukherjee, A. (2019). Economy-policy. Retrieved from https://www.businessstandard.com/article/economy-policy/india-going-cashless-may-be-the-story-of-prime-ministermodi-s-second-term-119060600143_1.html (accessed on 10 September 2019)

Mukhopadhyay, B. (2016). Understanding cashless payments in India. Financial Innovation, Vol.2,1-26.

Oye, N. D., lahad, N. A., Rahim, A.N. (2014). The history of UTAUT model and its impact on ICT acceptance and usage by academicians. Education and Information Technologies, 19 , 251-270.

Pal, J., Chandra, P., Kameswaran, V., Parameshwar, A. , Joshi , S. and Johri, A. (2018). Digital Payment and Its Discontents: Street Shops and the Indian Government's Push for Cashless Transactions. Proceedings of the $\mathrm{CHI}$ Conference on Human Factors in Computing Systems (Paper No. 229,21-26). Montreal, Canada.

Pavlou, P. A. (2003). Consumer Acceptance of Electronic Commerce: Integrating Trust and Risk with the Technology Acceptance Model. International Journal of Electronic Commerce, 7(3), 101-134

Polasik, M. and Maciejewski, K. (2009). Bariery rozwoju społeczeństwa bezgotówkowego w Polsce. (Barriers to the Development of Cashless Society in Poland.) In S. Partycki (Ed.). E- economy, Esociety in Central and Eastern Europe, Volume 2, Lublin, Wydawnictwo KUL.

Popescu, R. I., Corboş, R. A., \& Bunea, O. I. (2018). Influences on Urban Competitiveness Development from the Perspectives of Business and Local Authorities. Revista de Management Comparat International, 19(4), 359-371.

Porter, M.E. \& Heppelmann, J.E. (2014). How Smart, Connected Products Are Transforming Competition. Harvard Business Review, 92, 64-88. 
Reserve Bank of India. (2019). Guidelines for licensing of payments bank. Retrieved from: https://www.rbi.org.in/scripts/bs_viewcontent.aspx\%3FId\%3D2900

Rigdon, E.E. (2016). Choosing PLS path modeling as analytical method in European management research: A realist perspective. European Management Journal http://dx.doi.org/10.1016/j.emj.2016.05.006

Ronkko, M., McIntosh, C. M., \& Antonakis, J. (2015). On the adoption of partial least squares in psychological research: Caveat emptor. Personality and Individual Differences, 87, 76e84.

Rouse, A. and Corbitt, B. (2008). There's SEM and "SEM": A Critique of the Use of PLS Regression in Information Systems Research. ACIS 2008 Proceedings. 81. http://aisel.aisnet.org/acis2008/81

Salmony, M. (2011). Why Is Use of Cash Persisting? Critical Success Factors for Over- coming. Journal of Payments Strategy \& Systems, 5(3), 246-272.

Schneider, F. (2006). Shadow Economies and Corruption All Over the World: What do we Really Know? Economics: The Open-Access, Open-Assessment e-Journal. Retrieved from: http://ftp.iza.org/dp2315.pdf (accessed on 10 October 2019). Retrieved from:https://mpra.ub.unimuenchen.de/65934/1/MPRA_paper_65934.pdf (accessed on 10 October 2019).

Schneider, F. (2011). The shadow economy in Europe. Retrieved from: https://www.atkearney.com/documents/10192/1743816/The+Shadow+Economy+in+Europe+2013. pdf .(15 September,2019)

Schneider, F. (2013). The shadow economy in Europe. Retrieved from: https://www.atkearney.com/documents/10192/1743816/The+Shadow+Economy+in+Europe +2013.pdf(15September,2019)

Schuberth, F.,Jorg,H. and Dijkstra, K.T.(2018).Partial Least squares path modelling using ordinal categorical indicators. Quality and Quantity , 52:9-35.

Schuh, S. and Stavins , J. (2013). How Consumers Pay: Adoption and Use of Payments. Accounting and Finance Research, 2(2), 246-272.

Shashidhar, K. (2018). Was the boost in digital payments after demonetization temporary? Live-mint, industry. Retrieved from: https://www.livemint.com/Industry/yjsk66xEwwle700qcoC92N/Was-theboost-in-digital-payments-after-demonetization-tempo.html (acessed on September 2019).

Sichel, D. 1. (1997). The computer revolution: An economic perspective. Washington, DC: The Brookings Institution.

Singh, S., Bhattacharya, K. (2015). Does easy availability of cash effect corruption? Evidence from panel of countries. MPRA Paper 65934, Germany:University Library of Munich.

Sridhar, G. N. (2018). Two years after note ban digital transactions show robust growth. Business Line, Money and banking. Retrieved from:https://www.thehindubusinessline.com/money-andbanking/two-years-after- note-ban-digital-transactions-show-robust-growth/article25429396.ece (accessed on 15 September 2019).

Subrahmanya, K. N., Puttana, K.(2018). Payments transition in India - consumer preferences and policy shifts. Banks and Bank Systems, 13(4), 17-30.

Taylor, S., Todd, A.P. (1995). Understanding Information Technology Usage: A Test of Competing Models. Information Systems Research (6:2), 144-176.

Tunay, K., Tunay, N. \& Akhisar,I. (2015). Interaction Between Internet Banking and Bank Performance: The Case of Europe. Procedia - Social and Behavioral Sciences. 195. 363-368. 10.1016/j.sbspro.2015.06.335. 
Turel, O., Serenko , A. and Bontis, N.(2007). User acceptance of wireless short messaging services: Deconstructing perceived value. Information \& Management,44(1),63-73.

Venkatesh, V. and Davis. F. (2000). A Theoretical Extension of the Technology Acceptance Model: Four Longitudinal Field Studies. Management Science (46:2), 186-204.

Venkatesh, V., Michael, M.G., M. D., Gordon, B. D and Fred D. D (2003). User Acceptance of Information Technology: Toward a Unified View. MIS Quarterly (27:3), 425-478.

Wilson, J. (2017). Did Demonetisation Bring About a Digital Transaction Revolution? The Wire, Business. Retrieved from https://thewire. in/152625/digital-transactions demonetisation-detailedanalysis/ [Accessed 10 October 2019].

Zamfir, A. (2013). A strategic management model for service organizations. Business Excellence and Management, 3(3), 55-60.

Zandi, M., Singh, V. and Irving, J. (2013). The Impact of Electronic Payments on Economic Growth. Moody's Analytics. Retrieved from: https://usa.visa.com/dam/VCOM/download/corporate/media/moodys-economy (accessed at 15 September 2019).

Zhou, T. (2011). An empirical examination of initial trust in mobile banking. Internet Research, 21(5), 527-540. 